\title{
Ozone production chemistry in the presence of urban plumes $\dagger$
}

\author{
W. H. Brune, ${ }^{\text {*a }}$ B. C. Baier, ${ }^{a}$ J. Thomas, ${ }^{a b}$ X. Ren, ${ }^{c}$ R. C. Cohen, ${ }^{d}$ \\ S. E. Pusede, de E. C. Browne, ${ }^{\text {df }}$ A. H. Goldstein, ${ }^{9}$ D. R. Gentner, ${ }^{\text {h }}$ \\ F. N. Keutsch, ${ }^{i}$ J. A. Thornton, ${ }^{j}$ S. Harrold, ${ }^{j k}$ F. D. Lopez-Hilfiker ${ }^{j l}$ \\ and P. O. Wennberg ${ }^{\mathrm{m}}$
}

Received 1st December 2015, Accepted 23rd December 2015

DOI: $10.1039 / c 5 f d 00204 d$

Ozone pollution affects human health, especially in urban areas on hot sunny days. Its basic photochemistry has been known for decades and yet it is still not possible to correctly predict the high ozone levels that are the greatest threat. The CalNex_SJV study in Bakersfield CA in May/June 2010 provided an opportunity to examine ozone photochemistry in an urban area surrounded by agriculture. The measurement suite included hydroxyl $(\mathrm{OH})$, hydroperoxyl $\left(\mathrm{HO}_{2}\right)$, and $\mathrm{OH}$ reactivity, which are compared with the output of a photochemical box model. While the agreement is generally within combined uncertainties, measured $\mathrm{HO}_{2}$ far exceeds modeled $\mathrm{HO}_{2}$ in $\mathrm{NO}_{x}$-rich plumes. $\mathrm{OH}$ production and loss do not balance as they should in the morning, and the ozone production calculated with measured $\mathrm{HO}_{2}$ is a decade greater than that calculated with modeled $\mathrm{HO}_{2}$ when $\mathrm{NO}$ levels are high. Calculated ozone production using measured $\mathrm{HO}_{2}$ is twice that using modeled $\mathrm{HO}_{2}$, but this difference in calculated ozone production has minimal impact on the assessment of $\mathrm{NO}_{x}$-sensitivity or VOC-sensitivity for midday ozone production. Evidence from this study indicates that this important discrepancy is not due to the $\mathrm{HO}_{2}$ measurement or to the sampling of transported

\footnotetext{
${ }^{a}$ Department of Meteorology, Pennsylvania State University, University Park, PA 16802, USA. E-mail: whb2@ psu.edu

${ }^{b}$ Department of Earth and Planetary Sciences, Johns Hopkins University, Baltimore, MD 21218, USA ${ }^{c}$ NOAA Air Resources Laboratory, College Park, MD, 20740, USA

${ }^{d}$ Departments of Chemistry and Earth and Planetary Science, University of California, Berkeley, CA 94720, USA ${ }^{e}$ Department of Environmental Sciences, University of Virginia, Charlottesville, VA 22904, USA ${ }^{f}$ Department of Chemistry and Biochemistry, University of Colorado, Boulder, CO 80309, USA ${ }^{g}$ Department of Environmental Science, Policy, and Management, University of California, Berkeley, CA 94720 , USA

${ }^{h}$ Department of Chemical and Environmental Engineering, Yale University, New Haven, CT 06511, USA iDepartment of Chemistry and Chemical Biology, Harvard University, Cambridge, MA 02138, USA ${ }^{j}$ Department of Atmospheric Sciences, University of Washington, Seattle, WA 98195, USA ${ }^{k}$ Puget Sound Clean Air Agency, Seattle, WA 98101, USA

${ }^{l}$ Paul Scherrer Institut, Villigen, PSI, Switzerland

${ }^{m}$ The Linde Center for Global Environmental Science, Caltech, Pasadena, CA 91125, USA

$\dagger$ Electronic supplementary information (ESI) available. See DOI: 10.1039/c5fd00204d
} 
plumes but instead to either emissions of unknown organic species that accompany the $\mathrm{NO}$ emissions or unknown photochemistry involving nitrogen oxides and hydrogen oxides, possibly the hypothesized reaction $\mathrm{OH}+\mathrm{NO}+\mathrm{O}_{2} \rightarrow \mathrm{HO}_{2}+\mathrm{NO}_{2}$.

\section{Introduction}

Ground-level ozone $\left(\mathrm{O}_{3}\right)$ is a serious health hazard, ${ }^{1,2}$ with no known safe limit, and is estimated to cause millions of deaths per year globally. In the United States, urban ozone levels have decreased dramatically in the past two to three decades due to the significant investments made in understanding the cause of ozone pollution and to air quality regulations. ${ }^{3}$ These regulations have encouraged lower emissions of nitrogen dioxide $\left(\mathrm{NO}_{2}\right)$ and nitric oxide (NO) (collectively termed $\mathrm{NO}_{x}$ ) and volatile organic compounds (VOCs), which are the raw ingredients needed to produce ozone. Although ozone reductions in some parts of the United States appear to have leveled off, ozone reduction in the United States is a success story - one that should be emulated globally. However, with limited resources, much of the world cannot afford the investment the United States has made. The solution is an optimized approach that can target the specific emissions to which ozone production is most sensitive.

An optimized approach to ozone pollution reduction requires a solid scientific understanding of the causes of ozone pollution. The basic chemistry has been known for decades. ${ }^{4-6}$ Ozone production begins with the early morning production of the hydroxyl $(\mathrm{OH})$ and hydroperoxy $\left(\mathrm{HO}_{2}\right)$ radicals in the presence of $\mathrm{NO}_{x}$ $\left(\mathrm{NO}_{2}+\mathrm{NO}\right)$ and VOC emissions. Hydroxyl reacts with the VOCs, causing a cascade of reactive organic compounds, including organic peroxy radicals $\left(\mathrm{RO}_{2}\right)$ and $\mathrm{HO}_{2}$. The peroxy radicals react with $\mathrm{NO}$ to form peroxy radicals and $\mathrm{NO}_{2}$. Nitrogen dioxide is decomposed by ultraviolet sunlight to form NO and atomic oxygen, which immediately reacts with molecular oxygen $\left(\mathrm{O}_{2}\right)$ to form ozone. This process is the dominant production pathway for tropospheric ozone.

However, $\mathrm{NO}$ also reacts with $\mathrm{O}_{3}$ to make $\mathrm{NO}_{2}$, $\mathrm{NO}$ and $\mathrm{NO}_{2}$ come into a steadystate balance within tens of seconds, and $\mathrm{NO}_{2}$ then reacts with $\mathrm{OH}$ to terminate $\mathrm{NO}_{x}$ and $\mathrm{HO}_{x}\left(\mathrm{OH}+\mathrm{HO}_{2}\right)$ cycling. By this theory, the instantaneous ozone production, $P\left(\mathrm{O}_{3}\right)$, initially increases as NO increases, but then decreases with continued NO increase. The peak $P\left(\mathrm{O}_{3}\right)$ is a sensitive function of $\mathrm{HO}_{x}$ production. ${ }^{7-9}$ One simple test of the non-linear dependence of ozone production on $\mathrm{NO}_{x}$ is the so-called weekend-weekday effect, for which ozone is greatest on weekends when $\mathrm{NO}_{x}$ is less. ${ }^{\mathbf{1 0}}$

Despite this well-accepted theory, there are discrepancies between measured and ozone calculated by regional air quality models. The models agree with the observations on average, but tend to be too high for values below $50 \mathrm{ppbv}$ and too low for values approaching 80-90 ppbv and beyond. While models have had better agreement with observations for individual cities and times of the year, this discrepancy between modeled and measured ozone is found for several different models and urban areas. ${ }^{11-13}$ The causes of the disagreements between measured and modeled ozone are usually attributed to errors in the emissions inventories for nitrogen oxides $\left(\mathrm{NO}_{x}\right)$ and volatile organic compounds (VOCs), but there is some evidence that the well-tested theory may need some modification.

The budget equation for ozone is 


$$
\frac{\partial\left[\mathrm{O}_{3}\right]}{\partial t}=P_{\text {chem }}-L_{\text {chem }}+\frac{w_{\mathrm{e}} \Delta \mathrm{O}_{3}-u_{\mathrm{d}}\left[\mathrm{O}_{3}\right]}{H}-\nabla\left(\boldsymbol{v}\left[\mathrm{O}_{3}\right]\right),
$$

where $P_{\text {chem }}$ is the chemical $\mathrm{O}_{3}$ production rate, $L_{\text {chem }}$ is the loss rate, $w_{\mathrm{e}} \Delta \mathrm{O}_{3} / H$ is the ozone entrainment rate between the mixing layer and the free troposphere, $-u_{\mathrm{d}}\left[\mathrm{O}_{3}\right] / H$ is the ozone deposition rate, $H$ is the mixing layer height, and $-\nabla(v)$ $\left[\mathrm{O}_{3}\right]$ ) is the ozone advection rate by the mean wind, $\boldsymbol{v}$. Net ozone production can be calculated from 1.2-1.4,

$$
\begin{aligned}
& P\left(\mathrm{O}_{3}\right)=P_{\text {chem }}-L_{\text {chem }} \\
& P_{\text {chem }}=k_{\mathrm{NO}+\mathrm{HO}_{2}}[\mathrm{NO}]\left[\mathrm{HO}_{2}\right]+\sum_{i} k_{\mathrm{NO}+\mathrm{RO}_{2 \mathrm{i}}}[\mathrm{NO}]\left[\mathrm{RO}_{2 \mathrm{i}}\right] \\
& L_{\text {chem }}=f_{\mathrm{H}_{2} \mathrm{O}} J_{\mathrm{O}_{3}}\left[\mathrm{O}_{3}\right]+k_{\mathrm{O}_{3}+\mathrm{OH}}\left[\mathrm{O}_{3}\right][\mathrm{OH}]+k_{\mathrm{O}_{3}+\mathrm{HO}_{2}}\left[\mathrm{O}_{3}\right]\left[\mathrm{HO}_{2}\right]+k_{\mathrm{NO}_{2}+\mathrm{OH}}\left[\mathrm{NO}_{2}\right][\mathrm{OH}] \\
& +L\left(\mathrm{O}_{3}+\text { alkenes }\right)+L\left(\mathrm{O}_{3}+\text { halogens }\right)+P\left(\mathrm{RONO}_{2}\right)
\end{aligned}
$$

where $k$ 's are rate coefficients; $\mathrm{NO}$ is nitric oxide; $\mathrm{HO}_{2}$ is the hydroperoxyl radical; $\mathrm{RO}_{2}$ is the organic peroxyl radical; $J_{\mathrm{O}_{3}}$ is the photolysis frequency of $\mathrm{O}_{3} ; f_{\mathrm{H}_{2} \mathrm{O}}$ is the fraction of the excited state $\mathrm{O}\left({ }^{1} \mathrm{D}\right)$ atoms from $\mathrm{O}_{3}$ photolysis that react with $\mathrm{H}_{2} \mathrm{O}$; $\mathrm{OH}$ is the hydroxyl radical; and $\mathrm{RONO}_{2}$ represents organic nitrates.

In several studies, the measured $\mathrm{HO}_{2}$ often is less than modeled $\mathrm{HO}_{2}$ at low $\mathrm{NO}$, equals modeled $\mathrm{HO}_{2}$ when $\mathrm{NO}$ is about $1 \mathrm{ppbv}$, and increasingly exceeds modeled $\mathrm{HO}_{2}$ at increasingly higher NO abundances., ${ }^{\mathbf{9 1 4}-18}$ This measured-tomodeled difference is greatest when $\mathrm{HO}_{x}$ production is lowest, such as during morning rush hour, where the measured-to-modeled $\mathrm{HO}_{2}$ ratio can be higher than ten. It is least when $\mathrm{HO}_{x}$ production is greatest, such as during the afternoon. This greater-than-expected $\mathrm{HO}_{2}$ at higher $\mathrm{NO}$ is also inferred from peroxynitric acid $\left(\mathrm{HO}_{2} \mathrm{NO}_{2}\right)$ measurements in Mexico City in 2006. ${ }^{19}$ Therefore, ozone production $\left(\mathrm{PO}_{3}\right)$ calculated using the measured $\mathrm{HO}_{2}$ can exceed $P\left(\mathrm{O}_{3}\right)$ calculated using the modeled $\mathrm{HO}_{2}$. In addition, a direct measurement of the ozone production rate shows that measured $P\left(\mathrm{O}_{3}\right)$ is twice $P\left(\mathrm{O}_{3}\right)$ calculated using modeled $\mathrm{HO}_{2}$ and $\mathrm{RO}_{2}$, although the timing of the $P\left(\mathrm{O}_{3}\right)$ peak agrees better with the $P\left(\mathrm{O}_{3}\right)$ calculated with modeled $\mathrm{HO}_{2}$ than with $P\left(\mathrm{O}_{3}\right)$ calculated with measured $\mathrm{HO}_{2}{ }^{20,21}$ These observations are inconsistent with the current understanding of ozone production.

This discrepancy can be explained in several different ways. A first hypothesis is that the $\mathrm{HO}_{2}$ measurement is being affected by the atmospheric NO levels. A second hypothesis is that calculation of $P\left(\mathrm{O}_{3}\right)$ is being distorted by the averaging over plumes of $\mathrm{NO}_{x}$-rich and $\mathrm{HO}_{2}$-rich air so that the product of averaged measured $\left[\mathrm{HO}_{2}\right]$ and $[\mathrm{NO}]$ is larger than the average of the products of the plumescale $\mathrm{NO}$ and $\mathrm{HO}_{2}$ :

$$
\overline{\left[\mathrm{HO}_{2}\right]} \overline{[\mathrm{NO}]}>\overline{\left[\mathrm{HO}_{2}\right][\mathrm{NO}]}
$$

A third hypothesis is that $\mathrm{HO}_{x}$ measurements made when $\mathrm{NO}_{x}$ is not in photostationary state (PSS) are being compared to models that calculate $\mathrm{HO}_{x}$ while assuming an $\mathrm{NO}_{x}$ photostationary state. Because $\mathrm{NO}_{x}$ is often emitted from combustion as $\mathrm{NO}$, the $\mathrm{HO}_{x}$ loss due to $\mathrm{OH}+\mathrm{NO}_{2}$ would be less than in the model and measured $\mathrm{HO}_{2}$ would appear to be greater than modeled. The fourth 
hypothesis suggests that unknown $\mathrm{HO}_{x}$ sources are co-emitted with the $\mathrm{NO}_{x}$. The fifth hypothesis is that unknown chemistry is missing from the current understanding of the chemistry between nitrogen oxides and hydrogen oxides.

The multi-agency California Research at the Nexus of Air Quality and Climate Change-San Joaquin Valley (CalNex-SJV) study in Bakersfield CA during June 2010 meets the criteria needed to test these hypotheses. Bakersfield is situated in the southern San Joaquin Valley $180 \mathrm{~km}$ north-northwest of Los Angeles and experiences the second worst ozone pollution in California. ${ }^{22}$ It is surrounded by agricultural land, but at the same time has active oil and gas fields, an oil refinery and significant traffic on highways that has a higher fraction of diesel powered vehicles than other urban areas in the US. ${ }^{23}$ Its numerous point and distributed $\mathrm{NO}_{x}$ and VOC emission sources create a heterogeneous mix of plumes of different sizes and chemical composition. This combination of high VOC and $\mathrm{NO}_{x}$ emissions and the typically cloudless, hot weather causes high ozone abundances. Bakersfield CA typically has 90 exceedances of ozone air quality standards each year and, while the number has decreased during the past decade, it is still not in compliance with EPA air quality standards. ${ }^{22}$

The calculated ozone production has been examined for the San Joaquin Valley (SJV), including Bakersfield. In a study using midday (10:00-14:00 local time) measurements of temperature as a surrogate for $\mathrm{OH}$ reactivity from VOCs, $\mathrm{NO}_{x}$, and frequency of $\mathrm{O}_{3}$ exceedances, Pusede and Cohen showed that the calculated midday $P\left(\mathrm{O}_{3}\right)$ is consistent with a transition from VOC-sensitive to $\mathrm{NO}_{x}$-sensitive regimes for much of the SJV, starting first with higher maximum daytime temperatures $\left(34-45^{\circ} \mathrm{C}\right)$ followed by the beginning of a transition at more moderate temperatures $\left(28-33^{\circ} \mathrm{C}\right) .{ }^{24}$ In a second study focused on the CalNex-SJV site, Pusede et al. ${ }^{25}$ show that $P\left(\mathrm{O}_{3}\right)$ calculated with an analog model is $\mathrm{NO}_{x}$-sensitive for moderate-to-high temperatures, except for weekdays at moderate temperatures, for which it is VOCsensitive. These conclusions appear to be inconsistent with the $P\left(\mathrm{O}_{3}\right)$ calculated from the measurements of $\mathrm{HO}_{2}$ and $\mathrm{RO}_{2}$ as a function of $\mathrm{NO}$ described above. However, high NO and greater-than-expected $P\left(\mathrm{O}_{3}\right)$ occur mainly in the morning before 10:00 PST and it is not clear how this difference will affect the averaged $P\left(\mathrm{O}_{3}\right)$ sensitivity to $\mathrm{NO}_{x}$ and VOCs calculated for midday.

In this paper, we will test these hypotheses using primarily the $\mathrm{HO}_{2}$ and $\mathrm{NO}$ abundances measured during CalNex-SJV. First we will compare the measured $\mathrm{OH}, \mathrm{HO}_{2}$, and $\mathrm{OH}$ reactivities to those calculated by a near-explicit box model that is constrained by all other simultaneous field measurements in Bakersfield. Measured and modeled $\mathrm{OH}$ production and loss rates and ozone production from $\mathrm{HO}_{2}$ are also compared and discussed. Finally we add the evidence learned from this study to that from previous studies to assess the likelihood of the hypotheses for the greater-than-expected ozone production at greater NO abundances.

\section{Methods}

\section{Measurement site}

The CalNex 2010 field campaign in California consisted of aircraft and ship measurements, as well as two ground sites: one in Pasadena CA and a second in Bakersfield CA. This work focuses on the CalNex-SJV Bakersfield site (Fig. 1). A scaffolding tower $18 \mathrm{~m}$ high was erected in a field just to the east of a parking lot at the California Agricultural Experiment Station, which is located in south Bakersfield 
( $35.346153 \mathrm{~N}, 118.965519 \mathrm{~W})$. The land to the south is fields and settling ponds. Light businesses were located to the north, along with highway 58, a highly trafficked corridor, about $760 \mathrm{~m}$ away. A school bus facility was also located $600 \mathrm{~m}$ to the west.

Measurements were made from 15 May to 28 June 2010. For that time of year, the weather in Bakersfield is typically hot and dry, with temperatures routinely exceeding $37{ }^{\circ} \mathrm{C}$. However, 2010 was not a typical year. The temperature did not exceed $35{ }^{\circ} \mathrm{C}$ until the last three days, and during one week, the weather was cloudy with some light rain with temperatures ranging from $20{ }^{\circ} \mathrm{C}$ and to $25{ }^{\circ} \mathrm{C}$. Winds were generally from the north at $4 \mathrm{~ms}^{-1}$, although they were often calm and from the east in the hours around sunrise (Fig. 2).

\section{HO $_{x}$ measurements}

$\mathrm{OH}$ and $\mathrm{HO}_{2}$ were measured with Penn State's Ground-based Tropospheric Hydrogen-Oxides Sensor (GTHOS), ${ }^{26}$ which uses laser-induced fluorescence (LIF). The hydroxyl radical $(\mathrm{OH})$ is detected as the sampled air is pulled through a $1 \mathrm{~mm}$ inlet into low pressure $(\sim 6 \mathrm{hPa})$ and passes through the path of a laser tuned to the $\mathrm{Q}_{1}(2) \mathrm{OH}$ absorption line at $308 \mathrm{~nm}$, and then fluoresces. This fluorescence is measured in a first detection axis by a gated microchannel plate detector positioned perpendicular to the sample flow and the laser beam. The sampled air flows through the first detection axis, and has NO injected into it to react with $\mathrm{HO}_{2}$ to form $\mathrm{OH}$, which is then detected by LIF in a second detection axis in order to detect $\mathrm{HO}_{2}$.

A tunable dye laser pumped by a $532 \mathrm{~nm}$ Nd:YAG laser produces the $308 \mathrm{~nm}$ light used to detect $\mathrm{OH}$. This laser wavelength is alternately tuned by an etalon to

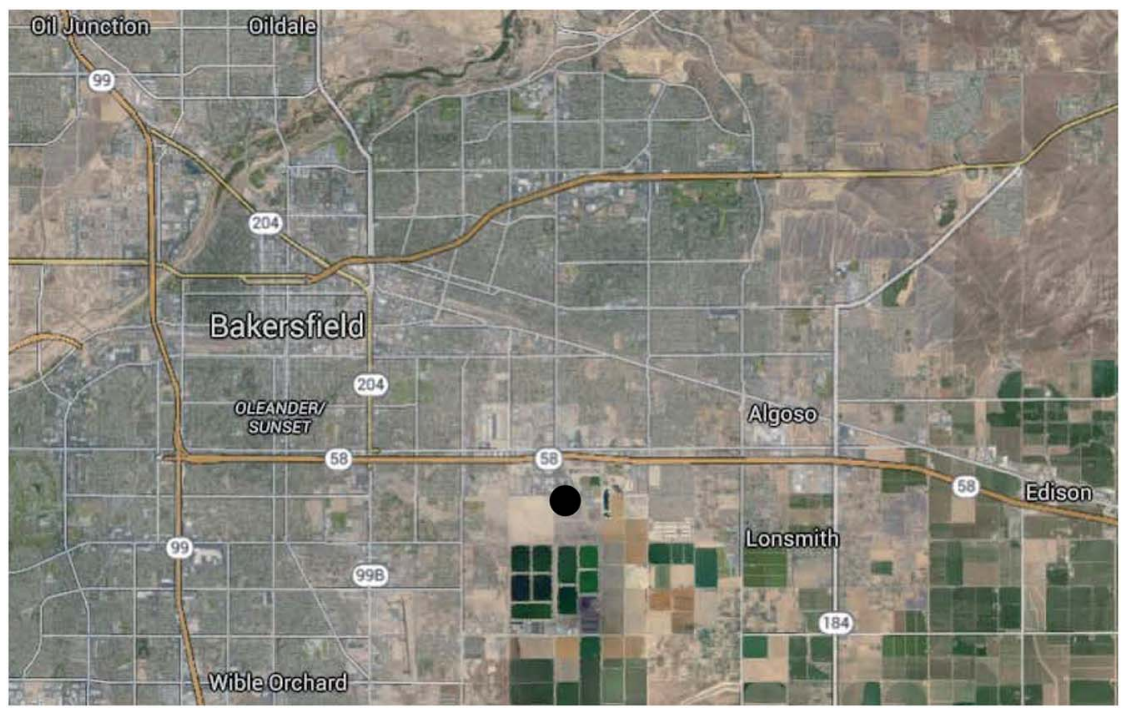

Fig. 1 Map of Bakersfield CA and location of the CalNex-SJV site (black dot) (Google, 2015). The site was at $35.346153^{\circ} \mathrm{N}$ and $118.965519^{\circ} \mathrm{W}$. The heavily traveled four-lane highway 58 was located $760 \mathrm{~m}$ to the north of the site. The nearest local road, East Belle Terrace, was $50 \mathrm{~m}$ to the north and had light traffic during the study period. 


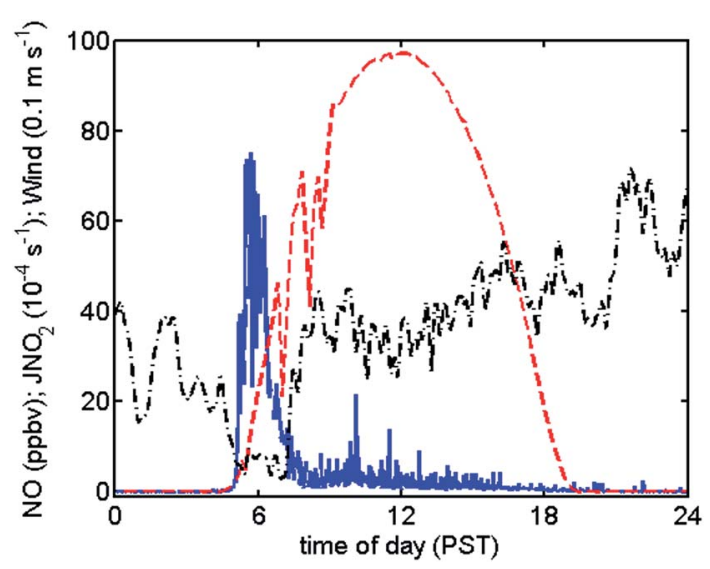

Fig. 2 Behavior of measured $\mathrm{NO}$ (blue solid line), $J\left(\mathrm{NO}_{2}\right)$ (red dashed line), and wind speed (dot-dashed black line) for day-of-the-year (day) 160, 9 June. This behavior is typical for most days during the study period, although the NO bump on day 160 was one of the largest. The widths of the NO spikes range from seconds to hours.

a wavelength where $\mathrm{OH}$ absorbs and then fluoresces or to the background on alternate sides of the $\mathrm{OH}$ absorption line, all within a 30 second cycle. The difference between these two signals is proportional to $\mathrm{OH}$. The proportionality constant is determined by laboratory and field calibrations. ${ }^{26}$ This method of measuring $\mathrm{OH}$ is referred to as $\mathrm{OH}_{\text {wave }}$. Wavelength modulation has been the most common method for measuring atmospheric $\mathrm{OH}$ by LIF.

A second $\mathrm{OH}$ measurement method involves injecting an $\mathrm{OH}$ reactant into the air to scavenge the $\mathrm{OH}$ before it is sampled through the instrument inlet. Reactant amounts are chosen to maximize the fraction of $\mathrm{OH}$ removed in the $10 \mathrm{~ms}$ between injection and entering the inlet and to simultaneously minimize the $\mathrm{OH}$ removed inside the instrument. Hexafluoropropylene $\left(\mathrm{C}_{3} \mathrm{~F}_{6}\right)$ was used as the $\mathrm{OH}$ scavenger. By turning $\mathrm{C}_{3} \mathrm{~F}_{6}$ injection on and off, the $\mathrm{OH}$ signal is found by subtracting the signal when injection is on from the signal when injection is off. This method is called $\mathrm{OH}_{\text {chem }}$. The difference between $\mathrm{OH}_{\text {wave }}$ and $\mathrm{OH}_{\text {chem }}$ is the $\mathrm{OH}$ from an interference, called $\mathrm{OH}_{\text {int }}$. The $\mathrm{OH}$ interference has the spectral signature of $\mathrm{OH}$, but all studies show that it is not laser-generated. To test the functionality of the $\mathrm{OH}_{\text {chem }}$ system, a UV lamp was affixed to the instrument near the inlet. The lamp, which photolyzed water vapor to make a large $\mathrm{OH}$ signal, was turned on for a few minutes three times a day to ensure that the $\mathrm{C}_{3} \mathrm{~F}_{6}$ injection was scavenging $\mathrm{OH}$ properly. For this paper, the $\mathrm{OH}$ measurements were all made with the chemical removal method.

Two years after CalNex-SJV, it was reported that some alkene-based and aromatic-based organic peroxides were also detected along with $\mathrm{HO}_{2}$ in most instruments that used NO to convert $\mathrm{HO}_{2}$ to $\mathrm{OH} .{ }^{27}$ Methods have been found to minimize this interference, but these methods were not used in the CalNex-SJV study. This sum of $\mathrm{HO}_{2}$ and a subset of $\mathrm{RO}_{2}$ has been called $\mathrm{HO}_{2}{ }^{*}$, which is then compared to modeled $\mathrm{HO}_{2}{ }^{*}{ }^{28}$ In this paper, our approach is to bound the possible $\mathrm{HO}_{2}$ values by subtracting all the modeled $\mathrm{RO}_{2}$ from $\mathrm{HO}_{2}$ * and calling this value $\mathrm{HO}_{2}$, which may be an overcorrection. This $\mathrm{HO}_{2}$ is actually the lower 
bound of $\mathrm{HO}_{2}$ and $\mathrm{HO}_{2}$ * is the upper bound. As will be seen, the main conclusions are not sensitive to the choice of $\mathrm{HO}_{2}$ between these two bounds.

In addition to $\mathrm{OH}$ and $\mathrm{HO}_{2}$ measurements, measurements were also made of $\mathrm{OH}$ reactivity, which is the inverse of the $\mathrm{OH}$ lifetime. ${ }^{29,30}$ Approximately $150 \mathrm{LPM}$ of ambient air is drawn into the instrument and flows through the aluminum flow tube ( $7.5 \mathrm{~cm}$ dia.). At the far end of the flow tube is a sampling inlet and an $\mathrm{OH}$ measurement system nearly identical to the one used in the main GTHOS system. Before the airflow reaches the sampling inlet, it flows past a movable source of $\mathrm{OH}$ called the wand. Inside the wand, 5 LPM of moist nitrogen flows past a mercury lamp, which photolyzes the water vapor to produce $\mathrm{OH}$ and $\mathrm{HO}_{2}$ and then jets out the detection axis. As the wand is moved farther away from the sampling inlet, the $\mathrm{OH}$ has more time to react with trace gases in the ambient air flowing through the tube and the $\mathrm{OH}$ signal decreases exponentially. Moving $10 \mathrm{~cm}$ is equivalent to a decay time of $140 \mathrm{~ms}$ and the wand completes a cycle in 30 seconds. The $\mathrm{OH}$ reactivity is the slope of the change in the log of the $\mathrm{OH}$ signal divided by the reaction time.

The $\mathrm{OH}$ reactivity decay is affected by atmospheric NO because $\mathrm{HO}_{2}+\mathrm{NO} \rightarrow$ $\mathrm{OH}+\mathrm{NO}_{2}$ recycles $\mathrm{OH}$ that has decayed, thus causing curvature in the $\mathrm{OH}$ decay. A least-squares linear fit to this curved decay produces a decay slope that is less than the real slope and thus produces an $\mathrm{OH}$ reactivity value that is too low. The effects of atmospheric $\mathrm{NO}$ on the $\mathrm{OH}$ reactivity measurement are minimized by applying the correction algorithm described in Shirley et al. ${ }^{31}$

The suite of measurements at the CalNex-SJV site was extensive as documented in the CalNex overview paper. ${ }^{32}$ It included meteorological parameters, inorganic species, volatile organic compounds (VOCs) and oxygenated VOCs, and many aerosol abundances and properties. Data used in this study were drawn primarily from measurements taken at or near the top of the measurement tower.

\section{Photochemical box modeling}

The simultaneous measurements of all available inorganic and organic species and meteorological parameters were used to calculate $\mathrm{HO}_{x}$ using the near-explicit Master Chemical Mechanism, Version 3.2 (MCMv3.2) $)^{33}$ in a box model framework developed by G. Wolfe. ${ }^{34}$ MCMv3.2 contains approximately 6700 unique chemical species and 17000 reactions. Measured VOCs that are included in the model are treated explicitly; those that are not represented in the model are aggregated into appropriate MCMv3.2 species based on $\mathrm{OH}$-reactivity or their molecular structure. It should be noted that isoprene chemistry in MCMv3.2 is replaced with explicit reactions detailed in Mao et al. ${ }^{35}$ Chemical species were assumed to have a lifetime of one day to prevent buildup in the model. Data were then averaged into ten-minute time intervals for the modeling and the comparisons to measurements.

Photolysis frequencies were not measured during CalNex-SJV, so instead they were calculated using the NCAR Tropospheric Ultraviolet and Visible Radiation Model. ${ }^{36}$ These calculations assume clear overhead skies with the overhead ozone column of 300 D.U. taken from satellite measurements; to correct for the effects of overhead cloud cover, photolysis frequencies were scaled by the ratio of the calculated $\mathrm{JNO}_{2}$ to $\mathrm{JNO}_{2}$ measured from a UV radiometer on the measurement tower. This same cloud correction factor was applied to the other calculated 
photolysis frequencies and has been shown to give accurate photolysis frequencies. ${ }^{37}$

Model results include days between 23 May and 28 June 2010 to allow for the greatest number of simultaneously measured chemical species to constrain the model. Data were taken from three periods when $\mathrm{HO}_{x}$, OH reactivity, and other chemical species important for this analysis were being measured: day 145-150; day 156-164; and day 166-174. They were averaged or interpolated into 10 minute time intervals for the model runs. For analysis of $\mathrm{HO}_{x}$ and $P\left(\mathrm{O}_{3}\right)$ as a function of NO, the 10 minute data were limited to hours between 7:00 and 17:00, a time period chosen to capture the portion of morning rush hour in which the photolysis and transport were well defined. All times are Pacific Standard Time even though the official time was Pacific Daylight Time during the field study.

\section{CalNex-SJV measurement and model uncertainties}

The absolute uncertainties for $\mathrm{OH}$ and $\mathrm{HO}_{2}$ are approximately $\pm 40 \%$ at the $2 \sigma$ confidence level. However, the subtraction of the $\mathrm{OH}$ signals with and without $\mathrm{C}_{3} \mathrm{~F}_{6}$ scavenging causes the $\mathrm{OH}$ limit-of-detection to be about $(2-3) \times 10^{5} \mathrm{~cm}^{-3}$. In addition, with the $\mathrm{RO}_{2}$ interference in the $\mathrm{HO}_{2}$ measurement, there is an additional uncertainty that can be about a factor of two. In studies after CalNex, our measurement strategy was revised to minimize the $\mathrm{RO}_{2}$ interference in the $\mathrm{HO}_{2}$ measurement. The uncertainty for the $\mathrm{OH}$ reactivity instrument is estimated to be $\pm 30 \%$ at $2 \sigma$ confidence. The uncertainties in the other measurements are given in Table $7 \mathrm{a}$ of the overview paper. ${ }^{32}$ The model uncertainty can be estimated from a global uncertainty and sensitivity analysis from a previous urban study using the RACM2 model. ${ }^{38}$ These two studies have similar uncertainties in their input measurements, reaction rate coefficients, and products, so the uncertainties in the modeled $\mathrm{OH}$ and $\mathrm{HO}_{2}$ for comparable urban areas should also be similar. Thus, the estimated $2 \sigma$ uncertainty is approximately $40 \%$ for $\mathrm{OH}$ and $\mathrm{HO}_{2}$. These uncertainties will be used to assess the significance of the comparisons between the measured and modeled $\mathrm{OH}, \mathrm{HO}_{2}$, and $\mathrm{OH}$ reactivity in this study.

\section{Results}

\section{Comparison of measured and modeled $\mathrm{OH}$ and $\mathrm{HO}_{2}$}

Understanding ozone production requires an understanding of $\mathrm{OH}$ and $\mathrm{HO}_{2}$. $\mathrm{A}$ first-order test of this chemistry is the comparison of the modeled and measured $\mathrm{OH}$ and $\mathrm{HO}_{2}$ as a function of the time of day (Fig. 3).

The median measured and modeled $\mathrm{OH}$ display the same diel behavior but the measured $\mathrm{OH}$ peaked at $(7.3 \pm 2.5) \times 10^{6} \mathrm{~cm}^{-3}$ while the modeled $\mathrm{OH}$ peaked at $(10.4 \pm 4.0) \times 10^{6} \mathrm{~cm}^{-3}$. This marginal statistical difference of $\sim 30 \%$ persists during the midday, although at sunrise and sunset, the modeled and measured $\mathrm{OH}$ agree. At night, the median measured $\mathrm{OH}$ is $3 \times 10^{5} \mathrm{~cm}^{-3}$, which is near the instrument detection limit and is consistent with the modeled nighttime $\mathrm{OH}$ of $3 \times 10^{4} \mathrm{~cm}^{-3}$.

The $\mathrm{OH}$ interference signal peaks at midday at $2 \times 10^{6} \mathrm{~cm}^{-3}$, is about $1 \times 10^{6}$ $\mathrm{cm}^{-3}$ at night, and is only about $25 \%$ of the $\mathrm{OH}$ determined by the chemical removal method. Interestingly, this $\mathrm{OH}$ interference signal is about the same as that observed in forests ${ }^{35,39}$ and in other $\operatorname{cities}^{17}$ and may have a common origin, 


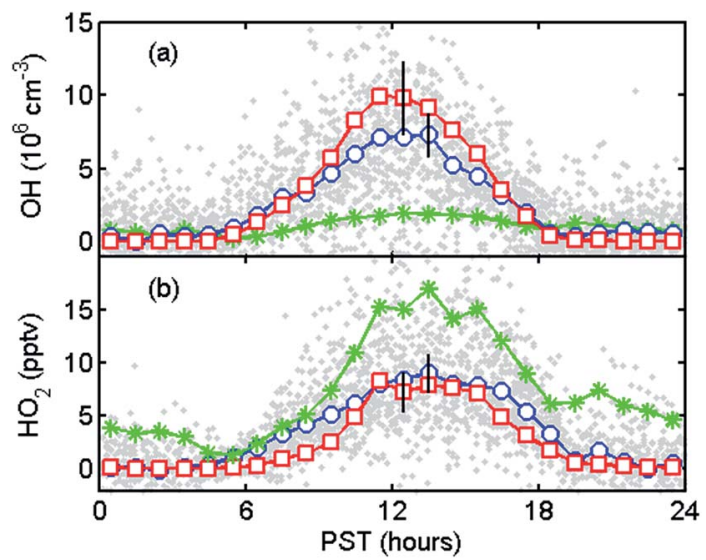

Fig. 3 Median diel variation of $\mathrm{HO}_{x}$. (a) $\mathrm{OH}\left(10^{6} \mathrm{~cm}^{-3}\right)$, measured (blue circles), modeled (red squares), and $\mathrm{OH}$ interference (green stars), with individual 10 min data for measured $\mathrm{OH}$ (gray dots); (b) $\mathrm{HO}_{2}$ (pptv), measured (blue circles), modeled (red squares), and measured $\mathrm{HO}_{2}$ with the $\mathrm{RO}_{2}$ interference (green stars), with individual 10 min data for measured $\mathrm{HO}_{2}$ (gray dots). Error bars are $\pm 1 \sigma$ confidence.

but because the $\mathrm{OH}$ is about 10 times larger in cities than in forests, the interference's effect of the measured $\mathrm{OH}$ is much more significant in forests than in cities.

Measured $\mathrm{HO}_{2}$ is on average about 7 pptv at midday and is within the combined uncertainties of the modeled $\mathrm{HO}_{2}$. Measured and modeled $\mathrm{HO}_{2}$ also agree at night, but in the morning, median measured $\mathrm{HO}_{2}$ is more than twice median modeled $\mathrm{HO}_{2}$. The $\mathrm{HO}_{2}$ with $\mathrm{RO}_{2}$ interference is about twice as large at midday and much larger at night. Thus measured and modeled $\mathrm{HO}_{2}$ agree within uncertainties for much of the day, if true $\mathrm{HO}_{2}$ is near the lower bound for measured $\mathrm{HO}_{2}$.

When median measured and modeled $\mathrm{OH}$ and $\mathrm{HO}_{2}$ are plotted against $\mathrm{NO}$ for the daytime, the modeled $\mathrm{OH}$ is similar to measured $\mathrm{OH}$ for $\mathrm{NO}$ up to about 10 ppbv (Fig. 4(a)). Measured $\mathrm{HO}_{2}$ and $\mathrm{HO}_{2}{ }^{*}$, on the other hand, begin deviating from modeled $\mathrm{HO}_{2}$ when NO is 1 ppbv, and are $\sim 10$ times larger when NO is 10 ppbv (Fig. 4(b)). This result is consistent with the previous reports of higher-thanexpected measured $\mathrm{HO}_{2}$ for conditions where $\mathrm{NO}$ is above 1 ppbv. Note that this discrepancy does not depend on uncertainties in removing the $\mathrm{RO}_{2}$ interference from the $\mathrm{HO}_{2}$ signal because $\mathrm{HO}_{2}$ and $\mathrm{HO}_{2}{ }^{*}$ behave the same way.

$\mathrm{HO}_{2}$ increases with the increasing production rate of $\mathrm{HO}_{x}, P\left(\mathrm{HO}_{x}\right)$, for each value of NO (Fig. 4(c)). The 10 minute data are binned into three $P\left(\mathrm{HO}_{x}\right)$ ranges: 1 $\times 10^{5} \mathrm{~cm}^{-3} \mathrm{~s}^{-1}<P\left(\mathrm{HO}_{x}\right)<5 \times 10^{6} \mathrm{~cm}^{-3} \mathrm{~s}^{-1}, 5 \times 10^{6} \mathrm{~cm}^{-3} \mathrm{~s}^{-1}<P\left(\mathrm{HO}_{x}\right)<10^{7} \mathrm{~cm}^{-3}$ $\mathrm{s}^{-1}$, and $P\left(\mathrm{HO}_{x}\right)>10^{7} \mathrm{~cm}^{-3} \mathrm{~s}^{-1}$. In Bakersfield, these ranges correspond to low $P\left(\mathrm{HO}_{x}\right)$ for early morning, late afternoon, or very cloudy days; medium $P\left(\mathrm{HO}_{x}\right)$ for mid-morning, midafternoon, or cloudy days; and high $P\left(\mathrm{HO}_{x}\right)$ for midday on sunny days. Note that both the measured and modeled $\mathrm{HO}_{2}$ are greater for greater $P\left(\mathrm{HO}_{x}\right)$, as would be expected, but modeled $\mathrm{HO}_{2}$ is more sensitive to $P\left(\mathrm{HO}_{x}\right)$ than measured $\mathrm{HO}_{2}$ is. Furthermore, in general, the measured-to-modeled $\mathrm{HO}_{2}$ ratio is least for the highest $P\left(\mathrm{HO}_{x}\right)$ and greatest for the lowest $P\left(\mathrm{HO}_{x}\right)$. Thus, regions with 


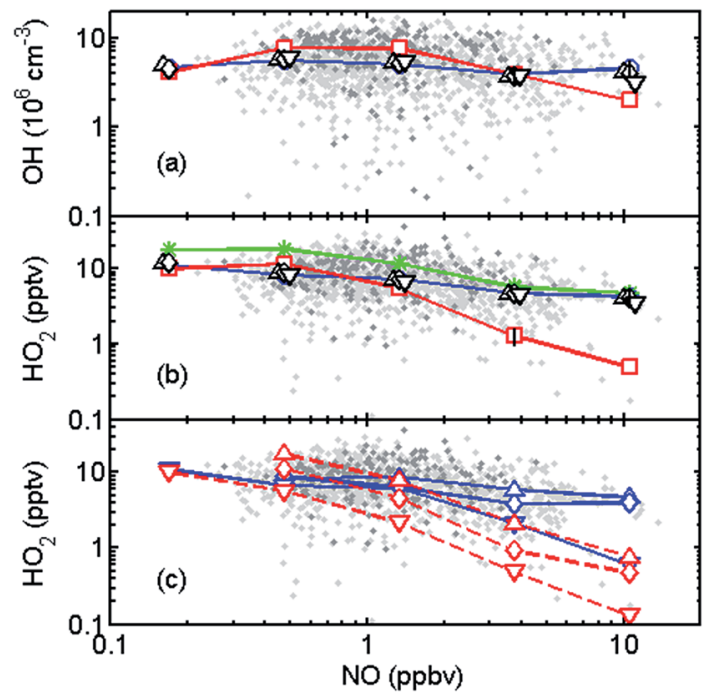

Fig. 4 Median behavior of $\mathrm{HO}_{x}$ as a function of $\mathrm{NO}$. (a) $\mathrm{OH}\left(10^{6} \mathrm{~cm}^{-3}\right)$, measured (blue circles), modeled (red squares), and measured averages of 20 seconds (upward pointing triangles), 1 minute (diamonds), and 1 hour (downward pointing triangles); (b) $\mathrm{HO}_{2}$ (pptv), measured (blue circles), modeled (red squares), measured $\mathrm{HO}_{2}$ with $\mathrm{RO}_{2}$ interference (green stars), and measured averages of 20 seconds (upward pointing triangles), 1 minute (diamonds), and 1 hour (downward pointing triangles); (c) $\mathrm{HO}_{2}$ (pptv), measured (solid blue lines) and modeled (dashed red lines), for $\mathrm{P}\left(\mathrm{HO}_{x}\right)>10^{7} \mathrm{~cm}^{-3} \mathrm{~s}^{-1}$ (upward triangles), $5 \times 10^{6}$ $\mathrm{cm}^{-3} \mathrm{~s}^{-1}<P\left(\mathrm{HO}_{x}\right)<10^{7} \mathrm{~cm}^{-3} \mathrm{~s}^{-1}$ (diamonds), and $1 \times 10^{5} \mathrm{~cm}^{-3} \mathrm{~s}^{-1}<\mathrm{P}\left(\mathrm{HO}_{x}\right)<5 \times 10^{6}$ $\mathrm{cm}^{-3} \mathrm{~s}^{-1}$ (downward triangles). Gray dots are individual 10 min measured data; darker gray dots are data measured between 12:00 and 15:00. Data are filtered for daytime hours between 7:00 and 17:00.

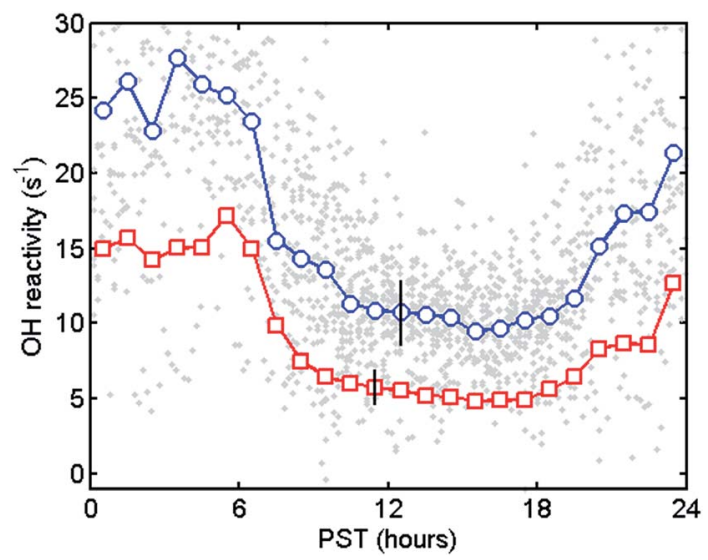

Fig. 5 Median diel variation of $\mathrm{OH}$ reactivity. Median measured (blue circles) and calculated from modeled chemical species (red squares), with individual $10 \mathrm{~min}$ data for measured $\mathrm{OH}$ reactivity (gray dots). A total of 339 out of 439210 minute data values are greater than $30 \mathrm{~s}^{-1}$ and are not shown. Error bars are $1 \mathrm{~s}$ confidence. 
higher $P\left(\mathrm{HO}_{x}\right)$ likely have a measured-to-modeled $\mathrm{HO}_{2}$ ratio that is closer to 1 even for higher NO values.

These differences between measured and modeled $\mathrm{OH}$ and $\mathrm{HO}_{2}$ are within the widely varying range of previous studies. ${ }^{40}$ Even this behavior as a function of $P\left(\mathrm{HO}_{x}\right)$ is the same as in previous studies. The CalNex results are quite similar to what is observed in an April 2009 SHARP study in Houston TX. ${ }^{17}$ An important difference between the Houston and Bakersfield studies is the higher daytime levels of NO in the Bakersfield study, levels that are closer to those observed in New York City in summer 2001. ${ }^{15}$ This difference influences the $P\left(\mathrm{O}_{3}\right)$ sensitivity to $\mathrm{NO}_{x}$ and VOCs.

\section{Comparison of measured to modeled $\mathrm{OH}$ reactivity}

The median measured $\mathrm{OH}$ reactivity was greatest at night when the atmospheric boundary layer height was lowest and was least during the late afternoon when the boundary layer height was greatest (Fig. 5). The median measured $\mathrm{OH}$ reactivity was as high at $26 \mathrm{~s}^{-1}$ at 4:00, dropped from $15 \mathrm{~s}^{-1}$ to $11 \mathrm{~s}^{-1}$ between 8:00 and 10:00, then slowly decreased to $9 \mathrm{~s}^{-1}$ at 17:00, after which it began a slow increase to nighttime values. Mean values are $\sim 20 \%$ higher because of the few large spikes. From day-to-day, $\mathrm{OH}$ reactivity varied from $5 \mathrm{~s}^{-1}$ to more than $50 \mathrm{~s}^{-1}$ at night and from about 3 to $20 \mathrm{~s}^{-1}$ during the day. The lowest values were on the few cool rainy days in May. The spikes in $\mathrm{OH}$ reactivity generally correlate to NO spikes, suggesting that a large fraction of $\mathrm{OH}$ reactivity in Bakersfield is due to anthropogenic emissions and combustion, ${ }^{41}$ but oxidation products, potentially from biogenic emissions from natural and agricultural sources, have large contributions to reactivity with high ambient temperatures. ${ }^{25}$

This measured $\mathrm{OH}$ reactivity is compared to the $\mathrm{OH}$ reactivity calculated from the measured chemical species and the modeled products of those measured chemical species. The ratio of model-calculated $\mathrm{OH}$ reactivity to measured $\mathrm{OH}$ reactivity is 0.59 at night and 0.53 during the day. In a cooler, rainy period at the beginning of the study (before day 150, 30 May), measured and calculated $\mathrm{OH}$ reactivity agreed to within $10 \%$. The missing $\mathrm{OH}$ reactivity tends to be greater when the temperature and ozone are higher, but these correlations are weak, suggesting that other factors such as unmeasured species may be contributing to the measured $\mathrm{OH}$ reactivity.

If only measured $\mathrm{OH}$ reactants are included in the calculated $\mathrm{OH}$ reactivity total, the calculated $\mathrm{OH}$ reactivity is only slightly less $(<10 \%)$ than the calculated $\mathrm{OH}$ reactivity that includes modeled chemical species. According to the model, $80 \%$ of the calculated $\mathrm{OH}$ reactivity is caused by 13 chemical species, with the most important being $\mathrm{NO}_{2}(22 \%)$, carbon monoxide (11\%), formaldehyde $(6 \%)$, ethanol (8\%), methanol (5\%), and heptanal + nonanal (5\%). The biogenic VOCs isoprene and limonene each contribute less than $2 \%$, thus indicating the dominance of anthropogenic VOCs in the calculated $\mathrm{OH}$ reactivity during this study. ${ }^{25}$ From this analysis, when NO is high, NO is a major $\mathrm{OH}$ sink, accounting for more than half the calculated $\mathrm{OH}$ reactivity in some plumes.

The $\mathrm{OH}$ reactivity is an indicator of the $\mathrm{OH}$ lifetime. For CalNex-SJV, the lifetime was $40 \mathrm{~ms}$ during the night and at sunrise and $\sim 100 \mathrm{~ms}$ during the day. With winds of $0.5 \mathrm{~m} \mathrm{~s}^{-1}$ during the early morning and $4 \mathrm{~m} \mathrm{~s}^{-1}$ during the rest of the day, $\mathrm{OH}$ achieved steady state ( $>3$ lifetimes) for air that had travelled less than 
2 meters. However, this view is too simplistic; not only must the lifetime of $\mathrm{OH}$ be considered but also the lifetime of $\mathrm{OH}$ sources ${ }^{42}$ and sudden changes in $\mathrm{OH}$ sources and sinks.

The effects on the $\mathrm{OH}$ value due to its sources and sinks can be seen by suddenly turning off the photolytic sources of $\mathrm{OH}$ and other radicals in a model. Using CalNex-SJV conditions and chemical species, a photochemical box model was run until it achieved steady state and then photolysis was terminated and the run continued for another 100 seconds to follow the decays of $\mathrm{OH}, \mathrm{HO}_{2}, \mathrm{NO}$, and other short-lived chemical species (Fig. 6). Initially $\mathrm{OH}$ drops at a rate about equal to the $\mathrm{OH}$ reactivity until the $\mathrm{OH}$ loss rate matches the $\mathrm{OH}$ production rate from recycling, primarily $\mathrm{HO}_{2}+\mathrm{NO}$ in this case. The $\mathrm{OH}$ decay then roughly parallels the decay of its primary source - $\mathrm{HO}_{2}$ times NO. The half-life of $\mathrm{NO}$ is $22 \mathrm{~s}, \mathrm{HO}_{2}$ $110 \mathrm{~s}$, and $\mathrm{OH} 13 \mathrm{~s}$, which is two orders-of-magnitude longer than indicated by the $\mathrm{OH}$ reactivity. In this case, the $\mathrm{HO}_{2}$ half-life is much longer than the NO half-life, but in the morning in CalNex-SJV, the half-life of $\mathrm{NO}$ is $60 \mathrm{~s}, \mathrm{HO}_{2} 13 \mathrm{~s}$, and $\mathrm{OH} 8 \mathrm{~s}$. Thus, while $\mathrm{OH}$ is in steady state with its sources and sinks in less than a second, its abundance is tied to the half-life of its sources as they respond to changes in their sources or sinks.

Typically in model-to-measurement $\mathrm{HO}_{x}$ comparisons, the model is constrained to $\mathrm{NO}, \mathrm{NO}_{2}, \mathrm{O}_{3}$, and all other measured chemical species except $\mathrm{OH}$ and $\mathrm{HO}_{2}$. We have used this method in the analysis for this paper. The model calculates the steady-state values for $\mathrm{OH}$ and $\mathrm{HO}_{2}$. However, $\mathrm{HO}_{2}$ may not be in steady state because of surface deposition, upwind cloud shadowing, or other $\mathrm{HO}_{x}$ production or loss that occurred within the tens of seconds prior to the measurement. For our example, the typical afternoon wind was $4 \mathrm{~m} \mathrm{~s}^{-1}$, so that in the $\mathrm{HO}_{2}$ half-life of $110 \mathrm{~s}$, the $\mathrm{HO}_{2}$ in an air parcel could be affected during its travel over a distance of almost half a kilometer. Thus $\mathrm{HO}_{2}$ could have values that are quite different from those calculated by a steady-state model constrained to the measurements made at the field site.

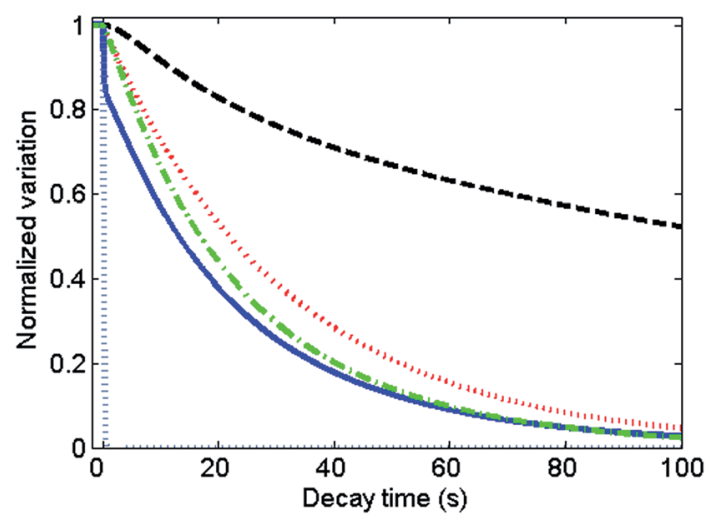

Fig. 6 Normalized modeled decays of $\mathrm{OH}$ (solid blue), $\mathrm{HO}_{2}$ (dashed black), $\mathrm{NO}$ (dotted red), $\mathrm{HO}_{2}$ times $\mathrm{NO}$ (dot-dashed green), and inverse of $\mathrm{OH}$ reactivity (leftmost dotted blue). This case is initialized with $\mathrm{O}_{3}(60 \mathrm{ppbv}), \mathrm{NO}_{2}$ (2.6 ppbv), $\mathrm{NO}(1.2 \mathrm{ppbv})$, and $\mathrm{OH}$ reactivity $\left(10 \mathrm{~s}^{-1}\right)$. 


\section{$\mathrm{OH}$ production and loss}

A critical consistency check of the measurements of $\mathrm{OH}, \mathrm{HO}_{2}$, and $\mathrm{OH}$ reactivity is the balance between production and loss for $\mathrm{OH}$. The loss rate for $\mathrm{OH}$ is product of the measured $\mathrm{OH}$ and $\mathrm{OH}$ reactivity; the production rate is all the sum of all the $\mathrm{OH}$ sources, including recycling, mostly from $\mathrm{HO}_{2}+\mathrm{NO}$, and primary production, mostly from $\mathrm{O}_{3}$ photolysis followed by $\mathrm{O}\left({ }^{1} \mathrm{D}\right)+\mathrm{H}_{2} \mathrm{O}$ and $\mathrm{HONO}$ photolysis. Most of these quantities and reaction rate coefficients are measured, making this consistency check very close to being independent of the model. The mean measured and modeled $\mathrm{OH}$ production and loss rates peaked at $(5-9) \times 10^{7} \mathrm{~cm}^{-3}$ $\mathrm{s}^{-1}$, (Fig. 7(a)). This $\mathrm{OH}$ production is lower by a factor of two compared to other US cities and by a factor of 6 compared to Mexico City in $2003 .{ }^{43}$ As in previous studies, measured $\mathrm{OH}$ production and loss match in the afternoon but not in the morning. From sunrise to almost noon, measured $\mathrm{OH}$ production and loss are both two to three times the modeled production/loss and measured $\mathrm{OH}$ production is about twice measured $\mathrm{OH}$ loss. Because of the short $\mathrm{OH}$ lifetime, these two must always match.

To resolve this discrepancy, one possibility is that the $\mathrm{OH}$ reactivity is biased low when ambient NO is high, which can result from two factors. First, the high $\mathrm{OH}$ reactivity in the morning reduces even the initial $\mathrm{OH}$ signal by about a decade compared to midday values, so that the low signal-to-noise of the decay and the uncertainty in the subtracted $\mathrm{OH}$ background signal strongly influence the calculated $\mathrm{OH}$ decays. Laboratory experiments indicate that too little background signal tends to get subtracted when the $\mathrm{OH}$ signal is small, causing the calculated decay to be smaller than it should be. Second, the correction factor to account for the recycling of $\mathrm{OH}$ by the reaction of $\mathrm{HO}_{2}$ and ambient $\mathrm{NO}$ in the $\mathrm{OH}$ reactivity instrument is dependent on $\mathrm{NO}$ and the $\mathrm{OH}$ reactivity, but it is typically 1.05 to

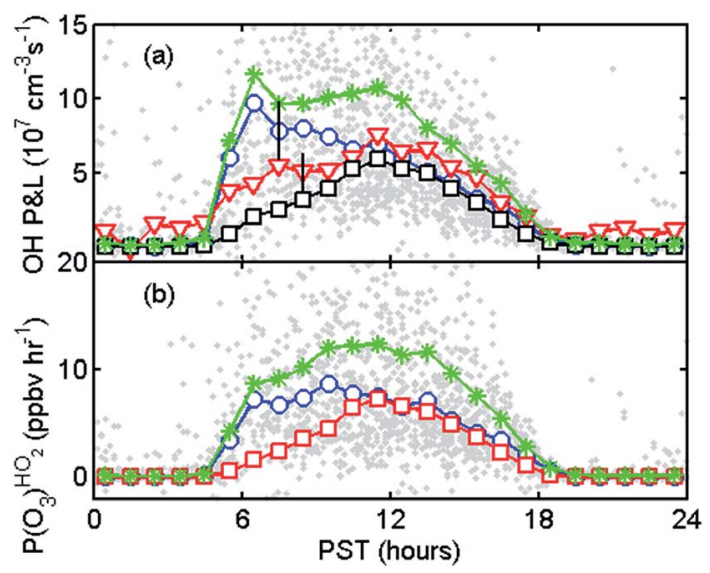

Fig. 7 Median diel variation of production and loss. (a) $\mathrm{OH}\left(10^{7} \mathrm{~cm}^{-3} \mathrm{~s}^{-1}\right)$, measured $\mathrm{OH}$ production (blue circles) and loss (red triangles), measured $\mathrm{OH}$ production using $\mathrm{HO}_{2}$ * instead of $\mathrm{HO}_{2}$ (green stars), modeled production and loss, which are equal (black squares), and individual 10 min production data using measured $\mathrm{HO}_{2}$ (gray dots); (b) ozone production from $\mathrm{HO}_{2}$ (pptv), $P\left(\mathrm{O}_{3}\right)^{\mathrm{HO}_{2}}$ calculated from measured $\mathrm{HO}_{2}$ (blue circles), modeled $\mathrm{HO}_{2}$ (red squares), and measured $\mathrm{HO}_{2}$ * (green stars), with individual 10 min data for $P\left(\mathrm{O}_{3}\right)^{\mathrm{HO}_{2}}$ calculated from measured $\mathrm{HO}_{2}$ (gray dots). 
1.1 for 1 ppbv of NO and increases to $6-10$ for $100 \mathrm{ppbv}$ of NO. The uncertainty in the correction factor is estimated to be $\pm 40 \%$ ( $2 \sigma$ confidence), based on repeated laboratory decays, although we think that this uncertainty can be cut in half. The combination of the tendency for insufficient background subtraction at low $\mathrm{OH}$ signals and uncertainty in the NO correction factor could be responsible for this discrepancy in the balance between $\mathrm{OH}$ production and loss. The other possibility is that the $\mathrm{HO}_{2}$ measurement is in error, which is discussed in a following section.

\section{Ozone production rate}

The ozone production from $\mathrm{HO}_{2}, P\left(\mathrm{O}_{3}\right)^{\mathrm{HO}_{2}}$, is only about half the total $P\left(\mathrm{O}_{3}\right)$, the other portion coming from $\mathrm{RO}_{2}$. We will confine our discussion only to calculated $P\left(\mathrm{O}_{3}\right)^{\mathrm{HO}_{2}}$ because $\mathrm{HO}_{2}$ was measured and $\mathrm{RO}_{2}$ was not. If $\mathrm{HO}_{2}$ is greater than expected at higher NO values, then by eqn (1.2), $P\left(\mathrm{O}_{3}\right)^{\mathrm{HO}_{2}}$ should also continue to increase for NO greater than $\sim 1$ ppbv, in contrast to the modeled value, which peaks when NO is near 1 ppbv and then decreases. This difference in measured and modeled $\mathrm{HO}_{2}$ translates directly into a difference in $P\left(\mathrm{O}_{3}\right)$ values that are calculated from measured and modeled values of $\mathrm{OH}$ and $\mathrm{HO}_{2}$ (Fig. 7(b)). $P\left(\mathrm{O}_{3}\right)^{\mathrm{HO}_{2}}$ calculated from measured $\mathrm{HO}_{x}$ is lower than $P\left(\mathrm{O}_{3}\right)^{\mathrm{HO}_{2}}$ calculated from modeled $\mathrm{HO}_{x}$ below $\sim 1 \mathrm{ppbv}$ and then becomes more than a decade larger for $\mathrm{NO}=10$ ppbv.

Most of this greater-than-expected $P\left(\mathrm{O}_{3}\right)^{\mathrm{HO}_{2}}$ occurs in the morning before 10:00. The cumulative median $P\left(\mathrm{O}_{3}\right)^{\mathrm{HO}_{2}}$ shown in Fig. 7(b) is 55 ppbv for the model and $97 \mathrm{ppbv}$ for the measurement. This cumulative production can be compared with the mean diel peak $\mathrm{O}_{3}$ of $58 \mathrm{ppbv}$ (range $\pm 20 \mathrm{ppbv}$ ). $P\left(\mathrm{O}_{3}\right)$ is about twice $P\left(\mathrm{O}_{3}\right)^{\mathrm{HO}_{2}}$, so the cumulative $P\left(\mathrm{O}_{3}\right)$ calculated from both modeled and measured $\mathrm{HO}_{2}$ are more than twice the observed ozone. At any given location, neither the calculated instantaneous nor cumulative ozone production are necessarily related to the peak ozone, which comes from not only the local production but also from production throughout the planetary boundary layer and from transport (eqn (1.1)). The calculated $P\left(\mathrm{O}_{3}\right)^{\mathrm{HO}_{2}}$ suggests that the CalNex_SJV site is in an ozone source region that contributes to the ozone production in the Bakersfield plume as it moves south during the day.

How does this difference in measured and modeled $P\left(\mathrm{O}_{3}\right)^{\mathrm{HO}_{2}}$ affect the assessment of $\mathrm{NO}_{x}$-sensitivity or VOC-sensitivity? In four urban areas, both measured and modeled $P\left(\mathrm{O}_{3}\right)^{\mathrm{HO}_{2}}$ were strongly VOC-sensitive during morning rush hour, but switched to weakly VOC-sensitive or $\mathrm{NO}_{x}$-sensitive from midmorning to mid-afternoon. ${ }^{43}$ For CalNex-SJV, mean midday NO was typically 1.5 ppbv, so that measured $\mathrm{HO}_{2}$ was less than twice modeled $\mathrm{HO}_{2}$. As a result, the greater-than-expected $P\left(\mathrm{O}_{3}\right)^{\mathrm{HO}_{2}}$ that occurs primarily in the morning does not significantly change the $P\left(\mathrm{O}_{3}\right)$ sensitivity to $\mathrm{NO}_{x}$ or VOCs during the 10:00 to 14:00 period used by Pusede et al. ${ }^{25}$ in their analysis.

\section{Possible cause of greater-than-expected $\mathrm{HO}_{2}$ and $\boldsymbol{P}\left(\mathrm{O}_{3}\right)^{\mathrm{HO}_{2}}$}

What could be the cause of the greater-than-expected $\mathrm{HO}_{2}$ and $P\left(\mathrm{O}_{3}\right)^{\mathrm{HO}_{2}}$ when NO exceeds 1 ppbv? We look at the five hypotheses presented in the Introduction.

A. $\mathrm{HO}_{2}$ measurement error. Measured $\mathrm{HO}_{2}$ could exceed modeled $\mathrm{HO}_{2}$ if there were an error in the absolute $\mathrm{HO}_{x}$ calibration. However, the $\mathrm{HO}_{2}$ calibration is tied to the $\mathrm{OH}$ calibration and measured $\mathrm{OH}$ is approximately equal to the 
modeled $\mathrm{OH}$. In addition, measured and modeled $\mathrm{HO}_{2}$ agree within uncertainties in the afternoon, especially if $\mathrm{HO}_{2}$ is close to the lower limit of possible values. Second, $\mathrm{HO}_{2}$ is detected by adding internally a few hundred ppmv of NO to convert $\mathrm{HO}_{2}$ to $\mathrm{OH}$, so the $10 \mathrm{ppbv}$ of atmospheric $\mathrm{NO}$ is overwhelmed by the injected NO. Third, a small $\mathrm{HO}_{2}$ signal offset is not responsible because the general differences between measured and modeled $\mathrm{HO}_{2}$ in Fig. 4 persists even when an offset of $2 \mathrm{pptv}$ is subtracted from the measured $\mathrm{HO}_{2}$. Such an offset is not observed and is about a decade higher than the limit-of-detection. Fourth, the $\mathrm{RO}_{2}$ interference due to alkene and aromatic peroxyl radicals is also unlikely for two reasons. The $\mathrm{RO}_{2}$ is more rapidly converted to $\mathrm{HO}_{2}$ as NO increases, but the $\mathrm{HO}_{2}$ is recycled with $\mathrm{OH}$, so the $\mathrm{RO}_{2}$-to- $-\mathrm{HO}_{2}$ ratio decreases as NO increases (Fig. 4(b)). Next, a previous study showed these unexpectedly high $\mathrm{HO}_{2}$ values at higher NO values in the upper troposphere where $\mathrm{RO}_{2}$ abundances are small. ${ }^{\mathbf{1 4}}$ Further evidence is provided by other studies using other instruments and even another $\mathrm{HO}_{2}$ measurement technique. ${ }^{9,15,16,18}$ So far, no $\mathrm{HO}_{2}$ measurement error has been found that would cause the greater-than-expected decrease in $P\left(\mathrm{O}_{3}\right)^{\mathrm{HO}_{2}}$ at high NO.

B. Measurement averaging. Does the average of measured $\mathrm{HO}_{2}$ times the average of measured $\mathrm{NO}$ equal the average of $\mathrm{HO}_{2}$ times $\mathrm{NO}$ ? This question can be answered by using high-resolution $\mathrm{HO}_{2}$ and $\mathrm{NO}$ measurements and averaging them together. The full width/half maximum (FWHM) of the NO plumes varied from a few seconds to well over an hour. However, for NO plumes with NO greater than $5 \mathrm{ppbv}, 80 \%$ of time was in plumes that were sampled for more than 20 seconds. As a result, we will use 20 seconds as the minimum time resolution for comparing the products of the averages to the averages of the products.

The averages of $\mathrm{HO}_{2}$ and $\mathrm{NO}$ were calculated for 20 seconds, 1 minute, 10 minutes, and 1 hour. These four different averages were plotted as a function of $\mathrm{NO}$ for $\mathrm{HO}_{2}$ in Fig. 4 and for calculated $P\left(\mathrm{O}_{3}\right)$ in Fig. 8. There are no significant differences among the four different averages. Thus, the greater-than-expected $\mathrm{HO}_{2}$ and $P\left(\mathrm{O}_{3}\right)$ at higher NO are not due to averaging over NO plume spikes.

In previous urban studies, point measurements have been compared to longpath absorption measurements to test the assumption that point measurements can adequately represent the integrated chemistry in urban plumes for measurement integration times of minutes or more. In a 1999 study in Nashville $\mathrm{TN}$, long-path and point measurements generally agreed to within $15 \%$ or better. ${ }^{44}$ In Mexico City in April 2003, point and long-path measurements of several VOCs were in good agreement for time scales of 5 minutes or more, although not for all VOCs. ${ }^{45,46}$ While these averages are in space while our averages are in time, the conclusion is that, if there are no unique emission sources nearby, point measurements can represent the photochemistry of an urban region.

C. Conditions when $\mathrm{NO}_{x}$ is not in photostationary state. The theoretical steady-state curve for the $\mathrm{HO}_{2}$ and $\mathrm{P}\left(\mathrm{O}_{3}\right)^{\mathrm{HO}_{2}}$ versus $\mathrm{NO}$ assumes that $\mathrm{HO}_{x}$ production is constant and $\mathrm{NO}_{x}$ is in photostationary state (PSS) as NO changes. Even though NO emissions are typically out of PSS for at most tens of seconds during the day, they are continually coming from thousands of sources and these plumes are continually contributing to ozone production. The analysis presented here makes no assumptions about $\mathrm{NO}_{x}$ PSS. As a result, the measured and modeled curves in Fig. 4 and 8 are averages over different $\mathrm{HO}_{x}$ production regimes 


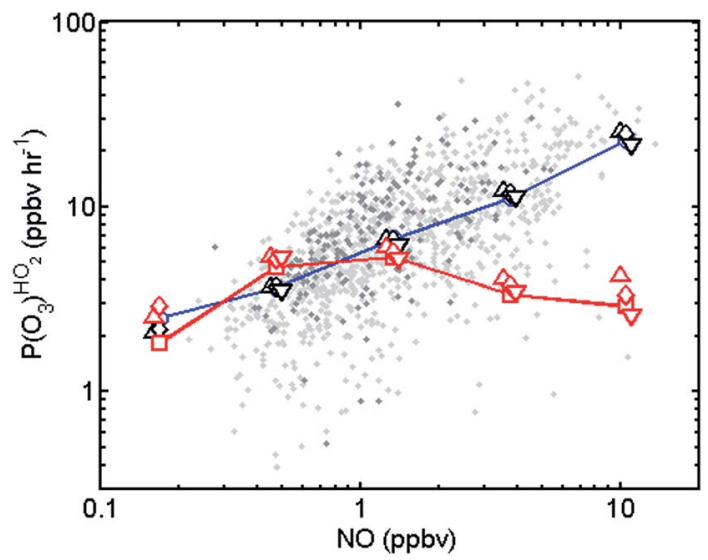

Fig. 8 Median behavior of the ozone production rate due to $\mathrm{HO}_{2}, P\left(\mathrm{O}_{3}\right)^{\mathrm{HO}_{2}}$, as a function of NO. 10 minute averages of measured (blue circles) and modeled (red squares) $P\left(\mathrm{O}_{3}\right)^{\mathrm{HO}_{2}}$ are plotted along with 20 second (upward pointing triangles), 1 minute (diamonds), and 1 hour (downward pointing triangles) averages. Gray dots are individual 10 min measured data; darker gray dots are data measured between 12:00 and 15:00 when the wind was from the north, although the points with greatest $\mathrm{NO}$ generally occurred when the winds were light and out of the east. Data are filtered for daytime hours between 7:00 and 17:00.

and may include measurements during conditions when $\mathrm{NO}_{x}$ is not in PSS. However, while $\mathrm{NO}_{x}$ may be out of PSS if we constrain the model-to-measured NO, $\mathrm{NO}_{2}$, and $\mathrm{O}_{3}$, the model does calculate steady-state values for $\mathrm{HO}_{2}$ and $\mathrm{OH}$. So a valid comparison between measured and modeled $\mathrm{HO}_{x}$ requires that $\mathrm{HO}_{x}$ be in steady state but not $\mathrm{NO}_{x}$.

We tested how close $\mathrm{NO}_{x}$ was to PSS using 1 minute averaged measurements. Comparisons were made between the model with $\mathrm{NO}, \mathrm{NO}_{2}$, and $\mathrm{O}_{3}$ constrained (i.e., measurements and no assumption of $\mathrm{NO}_{x}$ PSS) to calculations of $\mathrm{NO}_{x}$ PSS. These comparisons show that $\mathrm{NO}_{x}$ was generally within 10-20\% of PSS from 8:00 to 14:00, suggesting that NO had decreased about $\mathrm{e}^{-2}=0.14$ from its initial emission. The typical NO lifetime is $20-60$ seconds. When these lifetimes are multiplied by the wind speed and by 2 , the resulting product is the approximate distance the air must travel from a NO source so that the NO has decreased to 0.14 of its initial value. This distance was in the range of 100-150 m, a distance great enough that several sources could contribute to keeping the $\mathrm{NO}_{x}$ slightly out of photostationary state. Because $\mathrm{NO}_{x}$ was close to steady state, $\mathrm{HO}_{2}$ was likely to be in steady state in the morning when its lifetime was $13 \mathrm{~s}$ but not in the afternoon when its lifetime was 110 seconds. However, since the greater-than-expected $\mathrm{HO}_{2}$ occurs primarily in the morning when $\mathrm{HO}_{2}$ is in steady state, $\mathrm{NO}_{x}$ being out of PSS is not the cause of the greater-than-expected $\mathrm{HO}_{2}$ and calculated $P\left(\mathrm{O}_{3}\right)^{\mathrm{HO}_{2}}$.

D. Unknown $\mathrm{HO}_{2}$ sources accompanying $\mathrm{NO}$ emissions. Any unknown $\mathrm{HO}_{x}$ sources accompanying NO should show up in the $\mathrm{OH}$ reactivity measurement and in the comparison of the balance between $\mathrm{OH}$ production and loss (Fig. 7(a)). If the accompanying $\mathrm{HO}_{x}$ source is an $\mathrm{HO}_{2}$ source, such as an aldehyde, then it would also likely be an $\mathrm{OH}$ loss and appear in the $\mathrm{OH}$ reactivity. However, the agreement between measured and calculated $\mathrm{OH}$ reactivity is better when $\mathrm{NO}$ is high than when $\mathrm{NO}$ is low; calculated $\mathrm{OH}$ reactivity accounts for $\sim 50 \%$ of 
measured $\mathrm{OH}$ reactivity when NO was less than 1 ppbv but as much as $75 \%$ when NO is greater than 10 ppbv, just the opposite of expectations for an unknown $\mathrm{HO}_{2}$ source that is also an $\mathrm{OH}$ loss. Furthermore, an unknown $\mathrm{HO}_{2}$ source that acts also as an $\mathrm{OH}$ loss would cause the measured $\mathrm{OH}$ production to exceed the $\mathrm{OH}$ loss calculated from the known $\mathrm{HO}_{2}$ sources, but just the opposite is seen. These arguments are based on $\mathrm{OH}$ reactivity measurements that have an uncertain NO correction, so an unknown $\mathrm{HO}_{2}$ source cannot be entirely ruled out by these observations.

\section{E. Missing chemical mechanism}

For missing chemistry to cause the greater-than-expected $\mathrm{HO}_{2}$ dependence on NO, it must have a few characteristics. First, in order for $P\left(\mathrm{O}_{3}\right)$ to increase with NO as shown in Fig. 8, the $\mathrm{HO}_{2}$ production must be approximately proportional to NO because the difference between measured and modeled $P\left(\mathrm{O}_{3}\right)^{\mathrm{HO}_{2}}$ increases about a decade for each decade of increase in $\mathrm{NO}$ (Fig. 8). Second, the $\mathrm{HO}_{2}$ production rate from this chemistry would need to be approximately $5 \times 10^{7} \mathrm{~cm}^{-3} \mathrm{~s}^{-1}$ in order to balance the $\mathrm{HO}_{2}$ loss due to the reaction of $\mathrm{HO}_{2}$ with NO. This value comes from the difference in the $\mathrm{OH}$ production with measured and modeled $\mathrm{HO}_{2}$ (Fig. 7(a)). We know of no known chemical mechanism that can satisfy these two constraints. Yet with the uncertainty associated with the products of reactions such as $\mathrm{OH}+\mathrm{NO}_{2}$, unknown $\mathrm{HO}_{x}-\mathrm{NO}_{x}$ chemistry is a reasonable possibility for the greater-than-expected $\mathrm{HO}_{2}$ and calculated $\mathrm{P}\left(\mathrm{O}_{3}\right)^{\mathrm{HO}_{2}}$.

When we first observed this $\mathrm{HO}_{2}$ discrepancy a decade ago, we hypothesized that it might be due to the reaction sequence

$$
\begin{gathered}
\mathrm{OH}+\mathrm{NO} \rightarrow \mathrm{HONO}^{*} \\
\mathrm{HONO}^{*}+\mathrm{N}_{2} \rightarrow \mathrm{HONO} \\
\mathrm{HONO}^{*}+\mathrm{O}_{2} \rightarrow \mathrm{HO}_{2}+\mathrm{NO}_{2}
\end{gathered}
$$

The reaction to products $\mathrm{HO}_{2}+\mathrm{NO}$ is exothermic, $\Delta H=-94 \mathrm{~kJ} \mathrm{~mol}^{-1}$, and, to our knowledge, has never been tested. All studies of $\mathrm{OH}+\mathrm{NO}$ have been done at either low pressure or in the absence of molecular oxygen, according to Sander et al. and references therein. ${ }^{47}$ It is a difficult reaction to study because the $\mathrm{HO}_{2}$ produced recycles immediately to $\mathrm{OH}$ by $\mathrm{HO}_{2}+\mathrm{NO} \rightarrow \mathrm{OH}+\mathrm{NO}_{2}$. It is difficult to scavenge $\mathrm{HO}_{2}$ in laboratory studies, so this recycling would appear as a slower rate coefficient for $\mathrm{OH}+\mathrm{NO}+\mathrm{M}$, although laboratory studies of HONO formation have generally taken known recycling into account. This reaction can explain the observed $\mathrm{HO}_{2}$ discrepancy only if the formation of $\mathrm{HONO}^{*}$ is sped up in the presence of oxygen.

There is some evidence that this reaction could be occurring. Molecular energy calculations suggest that vibrationally excited HONO $\left(\nu_{\mathrm{OH}} \geq 3\right)$ can react with $\mathrm{O}_{2}$ to form $\mathrm{HO}_{2}+\mathrm{NO}_{2} \cdot{ }^{48}$ While this mechanism is a minor $\mathrm{HO}_{2}$ formation pathway if $\mathrm{HONO}^{*}$ is produced by the photo-excitation of HONO, it could be substantially greater if $\mathrm{HONO}^{*}$ is produced by the $\mathrm{OH}+\mathrm{NO}$ reaction. Other calculations suggest that the $\mathrm{H}$ atom can quickly hop from $\mathrm{O}$ atom to $\mathrm{O}$ atom in sub-nanosecond time scales, about five to ten times faster than the time between collisions with molecular oxygen and that the $\mathrm{H}$ atom could transfer to a colliding $\mathrm{O}_{2}$ molecule. ${ }^{49}$ 
In another study of the $\mathrm{OH}+$ acetylene reaction, $\mathrm{O}_{2}$ reacted with about $25 \%$ of the excited-state adducts before they could be collisionally relaxed. ${ }^{50}$ These studies suggest that it may indeed be possible for this reaction sequence to occur.

The results of our laboratory studies on this possible reaction have been decidedly mixed. However, the reaction would need to proceed with an effective bimolecular reaction rate of $(3-15) \times 10^{-11} \mathrm{~cm}^{3}$ molecule ${ }^{-1} \mathrm{~s}^{-1}$ in order to explain the $\mathrm{HO}_{2} / \mathrm{OH}$ ratio observed in this and previous ground-based studies made with GTHOS.

\section{Conclusions}

CalNex-SJV provides a good opportunity to compare measured and modeled oxidation chemistry in an environment with plumes of $\mathrm{NO}_{x}$ and their accompanying VOCs and OVOCs. The diel variation of the median measured and modeled $\mathrm{OH}$ and $\mathrm{HO}_{2}$ were generally well represented by the box model constrained by other simultaneous measurements except for $\mathrm{HO}_{2}$ during morning rush hour. As in many previous studies, the measured $\mathrm{HO}_{2}$ and the ozone production rate calculated from measured $\mathrm{HO}_{2}$ decreased much more slowly than the modeled $\mathrm{HO}_{2}$ and calculated $P\left(\mathrm{O}_{3}\right)^{\mathrm{HO}_{2}}$ as a function of NO. The amount of missing $\mathrm{OH}$ reactivity was roughly $45 \%$ of the total measured $\mathrm{OH}$ reactivity. Also as seen in most previous studies, the $\mathrm{OH}$ production and loss rates balance in the afternoon and at night, but in the morning, the production greatly exceeds the loss. These discrepancies could arise from issues with transport or issues with chemistry.

The presence of frequent $\mathrm{NO}_{x}$ plumes that lasted from seconds to an hour suggests that transport timescales were comparable to chemical timescales for radicals like $\mathrm{NO}$ and $\mathrm{HO}_{2}$. But even with strong winds $\left(4 \mathrm{~m} \mathrm{~s}^{-1}\right)$ from a major highway and the urban core, $\mathrm{NO}_{x}$ was close to a photostationary state as it was sampled at the field site. So, despite the heterogeneity of the sampled air masses, the comparison between the measured and modeled $\mathrm{OH}$ and $\mathrm{HO}_{2}$ was not significantly affected by these plumes in the morning, but may have been affected in the afternoon.

When the $\mathrm{OH}$ reactivity is between 5 and $25 \mathrm{~s}^{-1}$, as it was in this study, $\mathrm{OH}$ comes into balance with a change in its sources and sinks in much less than a second. However, $\mathrm{OH}$ will change only as fast as its sources and sinks change. In this study, the main $\mathrm{OH}$ source was $\mathrm{HO}_{2}+\mathrm{NO}$, so $\mathrm{OH}$ had a half-life of 13 seconds because $\mathrm{HO}_{2} \times \mathrm{NO}$ had a half-life of $16 \mathrm{~s}$. The results from this study show that point measurements can provide a valid test of urban oxidation chemistry if care is taken to ensure that $\mathrm{HO}_{2}$ is in steady state. $\mathrm{NO}_{x}$ does not have to be in steadystate if $\mathrm{NO}, \mathrm{NO}_{2}$, and $\mathrm{O}_{3}$ are constrained in the steady state model along with all other simultaneous measurements.

Greater-than-expected $\mathrm{HO}_{2}$ at high $\mathrm{NO}$ results in higher ozone production calculated from measured $\mathrm{HO}_{2}$, but it does not strongly influence the assessment of midday ozone production sensitivity to $\mathrm{NO}_{x}$ or VOCs. In the morning ozone production is VOC-limited whether modeled or measured $\mathrm{HO}_{2}$ is used to calculate ozone production. At midday the difference between measured and modeled $\mathrm{HO}_{2}$ is less, causing at most a small change in the assessment of $\mathrm{NO}_{x}$-sensitivity or VOC-sensitivity for ozone production.

Unknown $\mathrm{HO}_{x}-\mathrm{NO}_{x}$ chemistry emerged as one of the most likely causes for the greater-than-expected measured $\mathrm{HO}_{2}$ seen in this and several other previous 
studies. The proposed reaction of $\mathrm{OH}+\mathrm{NO}+\mathrm{O}_{2} \rightarrow \mathrm{HO}_{2}+\mathrm{NO}_{2}$ could resolve the $\mathrm{HO}_{2}$ discrepancy; laboratory and modeling kinetic studies are needed to test this hypothesis. This conclusion re-emphasizes the need to re-investigate $\mathrm{HO}_{x}-\mathrm{NO}_{x}$ photochemistry under atmospheric conditions.

\section{Acknowledgements}

We thank John Karlik, Rick Ramirez and the other scientists and staff at the University of California Kern County Extension Center for their hospitality and use of their facilities. Participation by WHB, BCB, JT was supported by grants from California Air Resources Board through the University of California, Berkeley (UCB subcontract 00007016) and from NSF (ATM-0706821).

\section{Notes and references}

1 M. L. Bell, A. McDermott, S. L. Zeger, J. M. Samet and F. Dominici, JAMA, J. Am. Med. Assoc., 2004, 19, 2372.

2 US EPA 2013, Final Report, http://cfpub.epa.gov/ncea/isa/recordisplay.cfm? deid=247492\#Download, accessed October 2015.

3 US EPA Air Trends, 2015, http://www3.epa.gov/airtrends/ozone.html, accessed November 2015.

4 A. J. Haagen-Smit and M. M. Fox, J. Air Waste Manage. Assoc., 1954, 4(3), 105136.

5 National Research Council, Rethinking the Ozone Problem in Urban and Regional Air Pollution, National Academy Press, Washington, D.C., 1991.

6 J. Calvert, J. Orlando, W. Stockwell and T. Wallington, The Mechanisms of Reactions Influencing Atmospheric Ozone, Oxford University Press, New York, NY, 2015, ISBN: 9780190233020.

7 L. Kleinman, P. Daum, Y. Lee, L. Nunnermacker, S. Springston, J. WeinsteinLloyd and J. Rudolph, J. Geophys. Res., 2001, 107, 4733.

8 J. Thornton, P. Woolridge, R. Cohen, M. Martinez, H. Harder, W. Brune, E. Williams, J. Roberts, F. Fehsenfeld, S. Hall, R. Shetter, B. Wert and A. Fried, J. Geophys. Res., 2002, 107, 4146.

9 M. Martinez, H. Harder, T. Kovacs, J. Simpas, J. Bassis, R. Lesher, W. Brune, G. Frost, E. Williams, C. Stroud, B. Jobson, J. Roberts, S. Hall, R. Shetter, B. Wert, A. Fried, B. Alicke, J. Stutz, V. Young, A. White and R. Zamora, J. Geophys. Res., 2003, 108, 4617.

10 I. Pollack, T. Ryerson, M. Trainer, D. Parrish, A. Andrews, E. Atlas, D. Blake, S. Brown, R. Commane, B. Daube and Coauthors, J. Geophys. Res., 2012, 117, D00V05.

11 D. Tong and D. Mauzerall, Atmos. Environ., 2006, 40, 3041.

12 K. Appel, A. B. Gilliland, G. Sarwar and R. C. Gilliam, Atmos. Environ., 2007, 41, 9603.

13 U. Im, R. Bianconi, E. Solazzo, I. Kioutsioukis, A. Badia, A. Balzarini, R. Baro, R. Bellasio, D. Brunner, C. Chemel and Coauthors, Atmos. Environ., 2015, 115, 404.

14 I. Faloona, D. Tan, W. Brune, L. Jaeglé, D. Jacob, Y. Kondo, M. Koike, R. Chatfield, R. Pueschel, G. Ferry, G. Sachse, S. Vay, B. Anderson, J. Hannon and H. Fuelberg, J. Geophys. Res., 2000, 105, 3771. 
15 X. Ren, H. Harder, M. Martinez, R. Lesher, A. Oliger, J. Simpas, W. Brune, J. Schwab, K. Demerjian, Y. He, X. Zhou and H. Gao, Atmos. Environ., 2003, 37, 1352 .

16 K. M. Emmerson, N. Carslaw, L. J. Carpenter, D. E. Heard, J. D. Lee and M. J. Pilling, J. Atoms. Chem., 2005, 52, 143-164.

17 X. Ren, D. van Duin, M. Cazorla, S. Chen, J. Mao, L. Zhang, W. Brune, J. Flynn, N. Grossberg, B. Lefer, B. Rappenglück, K. Wong, C. Tsai, J. Stutz, J. Dibb, B. Thomas Jobson, W. Luke and P. Kelley, J. Geophys. Res., 2013, 118, 5770.

18 Y. Kanaya, R. Cao, H. Akimoto, M. Fukuda, Y. Komazaki, Y. Yokouchi, M. Koike, H. Tanimoto, N. Takegawa and Y. Kondo, J. Geophys. Res., 2007, 112, D21312, DOI: 10.1029/2007jd008670.

19 K. M. Spencer, D. C. McCabe, J. D. Crounse, J. R. Olson, J. H. Crawford, A. J. Weinheimer, D. J. Knapp, D. D. Montzka, C. A. Cantrell, R. S. Hornbrook, R. L. Mauldin III and P. O. Wennberg, Atmos. Chem. Phys., 2009, 9, 3697-3707.

20 M. Cazorla and W. H. Brune, Atmos. Meas. Tech., 2010, 3, 545-555.

21 M. Cazorla, W. Brune, X. Ren and B. Lefer, Atmos. Chem. Phys., 2012, 12, 1203.

22 D. R. Gentner, G. Isaacman, D. R. Worton, A. W. H. Chan, T. R. Dallmann, L. Davis, S. Liu, D. A. Day, L. M. Russell, K. R. Wilson, R. Weber, A. Guha, R. A. Harley and A. H. Goldstein, Proc. Natl. Acad. Sci. U. S. A., 2012, 109, 18318-18323.

23 US EPA, 2015b, AirData, http://www3.epa.gov/airquality/airdata/, accessed November 2015.

24 S. E. Pusede and R. C. Cohen, Atmos. Chem. Phys., 2012, 12, 8323-8339.

25 S. E. Pusede, D. R. Gentner, P. J. Woolridge, E. C. Browne, A. W. Rollins, K.-E. Min, A. R. Russell, J. Thomas, L. Zhang, W. H. Brune and Coauthors, Atmos. Chem. Phys., 2014, 14, 3373-3395.

26 I. Faloona, D. Tan, R. Lesher, N. Hazen, C. Frame, J. Simpas, H. Harder, M. Martinez, P. Di Carlo, X. Ren and W. Brune, J. Atmos. Chem., 2004, 47, 139.

27 H. Fuchs, B. Bohn, A. Hofzumahaus, F. Holland, K. Lu, S. Nehr, F. Roher and A. Wahner, Atmos. Meas. Tech., 2011, 4, 1209.

28 S. M. Griffith, R. F. Hansen, S. Dusanter, P. S. Stevens, M. Alaghmand, S. B. Bertman, M. A. Carroll, M. Erickson, M. Galloway, N. Grossberg and Coauthors, Atmos. Chem. Phys., 2013, 13, 5403-5423, DOI: 10.5194/acp-135403-2013.

29 T. Kovacs and W. Brune, J. Atmos. Chem., 2001, 39, 105.

30 J. Mao, X. Ren, W. H. Brune, J. R. Olson, J. H. Crawford, A. Fried, L. G. Huey, R. C. Cohen, B. Heikes, H. B. Singh, D. R. Blake, G. W. Sachse, G. S. Diskin, S. R. Hall and R. E. Shetter, Atmos. Chem. Phys., 2009, 9, 163-173.

31 T. Shirley, W. H. Brune, X. Ren, J. Mao, R. Lesher, B. Cardenas, R. Volkamer, L. T. Molina, M. J. Molina, B. Lamb, E. Velasco, T. Jobson and M. Alexander, Atmos. Chem. Phys., 2006, 6, 2753-2765.

32 T. Ryerson, A. Andrews, W. Angevine, T. Bates, C. Brock, B. Cairns, R. Cohen, O. Cooper, J. de Gouw and F. Fehsenfeld, J. Geophys. Res., 2013, 118, 5830.

33 M. Jenkin, S. Saunders and M. Pilling, Atmos. Environ., 1997, 31, 81.

34 G. M. Wolfe and J. A. Thornton, Atmos. Chem. Phys., 2011, 11, 77-101.

35 J. Mao, X. Ren, L. Zhang, D. M. van Duin, R. C. Cohen, J.-H. Park, A. H. Goldstein, F. Paulot, M. R. Beaver, J. D. Crounse and Coauthors, Atmos. Chem. Phys., 2012, 12, 8009-8020. 
36 S. Madronich and S. Flocke, Environmental Photochemistry, Springer Berlin Heidelberg, 1999.

37 R. E. Shetter, L. Cinquini, S. R. Hall and S. Madronich, J. Geophys. Res., 2002, 107, PEM 6-1-PEM 6-12, DOI: 10.1029/2001jd001320.

38 S. Chen and W. H. Brune, Atmos. Environ., 2012, 55, 288-296, DOI: 10.1016/ j.atmosenv.2012.03.061.

39 K. Hens, A. Novelli, M. Martinez, J. Auld, J. R. Axinte, R. Bohn, B. H. Fischer, P. Keronen, D. Kubistin, A. C. Nölscher and Coauthors, Atmos. Chem. Phys., 2014, 14, 8723-8747, DOI: 10.5194/acp-14-8723-2014.

40 D. Stone, L. K. Whalley and D. E. Heard, Chem. Soc. Rev., 2012, 41, 6348-6404.

41 D. R. Gentner, T. B. Ford, A. Guha, J. Brioude, W. M. Angevine, J. A. de Gouw, C. Warneke, J. B. Gilman, T. B. Ryerson, J. Peischl, S. Meinardi, D. R. Blake, E. Atlas, W. A. Lonneman, T. E. Kleindienst, M. R. Beaver, J. M. St. Clair, P. O. Wennberg, T. C. VandenBoer, M. Z. Markovic, J. G. Murphy, R. A. Harley and A. H. Goldstein, Atmos. Chem. Phys., 2014, 14, 4955-4978, DOI: 10.5194/acp-14-4955-2014.

42 N. Bell, D. E. Heard, M. J. Pilling and A. S. Tomlin, Atmos. Environ., 2003, 37, 2193-2205.

43 J. Mao, X. Ren, S. Chen, W. H. Brune, Z. Chen, M. Martinez, H. Harder, B. Lefer, B. Rappengluck, J. Flynn and M. Leuchner, Atmos. Environ., 2010, 44, 4107.

44 J. A. Thornton, P. J. Wooldridge, R. C. Cohen, E. J. Williams, D. Hereid, F. C. Fehsenfeld, J. Stutz and B. Alicke, J. Geophys. Res., 2003, 108, 4496, DOI: $10.1029 / 2003$ jd003559.

45 E. Velasco, B. Lamb, H. Westberg, E. Allwine, G. Sosa, J. L. Arriaga-Colina, B. T. Jobson, M. L. Alexander, P. Prazeller, W. B. Knighton, T. M. Rogers, M. Grutter, S. C. Herndon, C. E. Kolb, M. Zavala, B. de Foy, R. Volkamer, L. T. Molina and M. J. Molina, Atmos. Chem. Phys., 2007, 7, 329-353.

46 B. T. Jobson, R. A. Volkamer, E. Velasco, G. Allwine, H. Westberg, B. K. Lamb, M. L. Alexander, C. M. Berkowitz and L. T. Molina, Atmos. Chem. Phys., 2010, 10, 1989-2005.

47 S. P. Sander, J. Abbatt, J. R. Barker, J. B. Burkholder, R. R. Friedl, D. M. Golden, R. E. Huie, C. E. Kolb, M. J. Kurylo, G. K. Moortgat, V. L. Orkin and P. H. Wine, JPL Publication, Pasadena, CA, 2012, pp. 10-6, http:// www.jpldataeval.jpl.nasa.gov.

48 M. Staikova, D. J. Donaldson and J. S. Francisco, J. Phys. Chem. A, 2002, 106, 3023-3028.

49 Y. Miller, G. M. Chaban, B. J. Finlayson-Pitts and R. B. Gerber, J. Phys. Chem. A, 2006, 110, 5342-5354.

50 D. R. Glowacki, J. Lockhart, M. A. Blitz, S. J. Klippenstein, M. J. Pilling, S. H. Robertson and P. W. Seakins, Science, 2012, 337, 1066, DOI: 10.1126/ science.1224106. 